\title{
Subaortastenose bij de newfoundland: erfelijkheid, pathofysiologie, diagnose, prognose en fokadvies
}

\author{
Subaortic stenosis in the Newfoundland: \\ heredity, pathophysiology, diagnosis, prognosis and breeding advice
}

\author{
${ }^{1}$ K. Caestecker, ${ }^{2}$ L. Peelman, ${ }^{3}$ V. Bavegems \\ ${ }^{1}$ Vakgroep Vergelijkende Fysiologie en Biometrie \\ ${ }^{2}$ Vakgroep Voeding, Genetica en Ethologie \\ ${ }^{3}$ Vakgroep Geneeskunde en Klinische Biologie van de Kleine Huisdieren \\ Faculteit Diergeneeskunde, Universiteit Gent, Salisburylaan 133, B-9820 Merelbeke, België \\ kevin.caestecker@ugent.be
}

\begin{abstract}
SAMENVATTING
Subaortastenose is een progressieve ontwikkelingsstoornis gekenmerkt door een obstructie van de linker ventriculaire uitstroomtractus net onder de aortaklep. Een dominant overervingstype met variabele penetrantie wordt algemeen als oorzaak beschouwd. Bij muizen is homozygotie voor het allel $E g f r^{\text {waz }}$ in combinatie met een mutatie in het Ptpn11-gen geassocieerd met gevoeligheid voor een aandoening gelijkend op subaortastenose bij de newfoundland. De diagnose gebeurt op basis van de anamnese, auscultatie, elektrocardiografie, thoraxradiografie, echocardiografie en hartkatheterisatie. Bij auscultatie wordt een (holo)systolisch, vaak schurend, crescendo-decrescendo bijgeruis gehoord met een maximale intensiteit ter hoogte van de linkerhartbasis. Echocardiografisch worden de stenose en de veranderingen van de linker ventriculaire uitstroomtractus nagegaan, alsook de snelheid van de bloedstroom en de drukgradiënt gemeten over de aortaklep, de verhouding van de oppervlakte van de linker ventriculaire uitstroomtractus en de oppervlakte van de aorta en de oppervlakte ter hoogte van de stenose. De prognose is variabel. Fokadvies is niet eenvoudig en wordt gegeven op basis van echocardiografische screening op de leeftijd van achttien maanden.
\end{abstract}

\section{ABSTRACT}

Subaortic stenosis is a narrowing of the left ventricular outflow tract just below the aortic valve, and is one of the most diagnosed congenital inherited heart diseases in the Newfoundland. The classification of subaortic stenosis is based on the lesions or the findings on echocardiography. Although the mode of inheritance is uncertain, a dominant trait with variable penetrance is generally accepted. The Epidermal Growth Factor Receptor oncogene is, together with the Ptpn11-gene, a possible candidate gene to be involved in this disease. The diagnosis is particulary based on auscultation and echocardiography. The prognosis is variable and breeding advice is based on echocardiographic screening at the age of eighteen months; however, it remains a difficult issue.

\section{INLEIDING}

Subaortastenose is een erfelijke ontwikkelingsstoornis van het hart die ondermeer bij de hond voorkomt. Er is een duidelijke raspredispositie waarbij de newfoundland een belangrijke plaats inneemt. Precieze cijfers over de prevalentie van deze erfelijke aandoening zijn in de literatuur niet te vinden, maar over één zaak is er een duidelijke consensus: subaortastenose is één van de meest voorkomende hartaandoeningen bij de hond. Kienle heeft het in 1998 over de meest gediagnosticeerde hartaandoening tijdens de periode 1986-1996 in de Noord-Amerikaanse diergeneeskundige universiteiten. De ernst van deze aandoening mag niet worden onderschat. Het is dan ook verantwoord voldoende aandacht te besteden aan de diagnostiek van subaortastenose en de verdere bege- leiding van de patiënt. Dit artikel heeft als doel de hoofdzaken van de echocardiografische diagnosestelling voor de praktiserende dierenarts naar voor te brengen. Op de behandeling van subaortastenose bij de individuele patiënt wordt niet ingegaan. De nadruk wordt gelegd op het begeleiden van de volledige hondenpopulatie door middel van gepast fokadvies om zo de frequentie van subaortastenose te beperken en uiteindelijk terug te dringen.

\section{DEFINITIE EN CLASSIFICATIE VAN SUBAORTA- STENOSE}

Subaortastenose (SAS) is een progressieve aandoening van de linker ventriculaire uitstroomtractus (LVOT - left ventricular outflow tract) waarbij er zich net onder de aortaklep een obstructie bevindt die wordt 


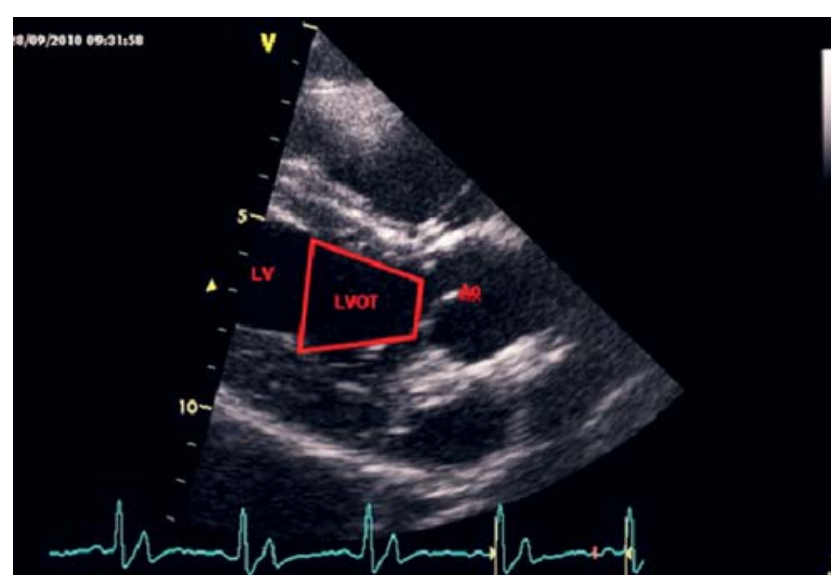

Figuur 1. Overlangse doorsnede op 2D-echocardiografie van de LVOT van een normaal individu (LV: linkerventrikel - LVOT: linker ventriculaire uitstroomtractus Ao: aorta).

gevormd door een fibreuze rand of ring (Kienle, 1998; MacDonald, 2006). De LVOT wordt door Kienle (1998) anatomisch gedefinieerd. Het is een afgeknotte kegel die wordt begrensd door het craniolaterale deel van de vrije wand van het linkerventrikel, het membraneuze en musculaire gedeelte van het ventriculaire septum ter hoogte van de hartbasis en de anterieure cuspis van de mitralisklep met zijn geassocieerde structuren. De anatomie van de LVOT wordt bekeken op echocardiografie als één van de pijlers om de diagnose te stellen. Bijgevolg is het van belang de morfologie van een normale LVOT in gedachten te hebben. Op overlangse doorsnede is de LVOT te zien als een trapezium die een tweedimensionale projectie is van de afgeknotte kegel met aan de insertie van de aortaklep de top en ter hoogte van het ventrikel de basis (Figuur 1). Figuur 2 toont een dwarse doorsnede van de hierboven beschreven afgeknotte kegel ter hoogte van de cuspes van de aortaklep. Naast het beoordelen van de subvalvulaire regio op overlangse doorsnede, is bij screening voor SAS het evalueren van een subvalvulair beeld op dwarse doorsnede eveneens belangrijk (Bussadori et al., 2000).

Het is belangrijk te beklemtonen dat SAS een progressieve aandoening is die tot de leeftijd van 18 maanden kan evolueren. SAS begint met kleine fibreuze nodules op het endocard. Deze nodules ontwikkelen zich geleidelijk aan gedurende de eerste levensmaanden (MacDonald, 2006). Hieruit volgt dat de graad van stenose eveneens een progressief veranderlijke waarde is. Pyle et al. (1976) stelden een classificatie op volgens drie graden. Vroege laesies worden geclassificeerd als graad 1 en ontwikkelen zich tijdens de eerste zes maanden van het leven. Deze laesies bestaan uit witte verheven nodules op het interventriculaire septum net onder de aortakleppen en veroorzaken zelden een bijgeruis. Laesies van graad 2 zijn smalle fibrotische kammen die de LVOT reeds gedeeltelijk kunnen omgeven. Hierbij kan een bijgeruis van graad I tot III/VI worden waargenomen. Graad 3 is de meest ernstige vorm van SAS. Hierbij omringt een fibreuze band of kam, fibromusculaire tunnel of fibreuze kraag de

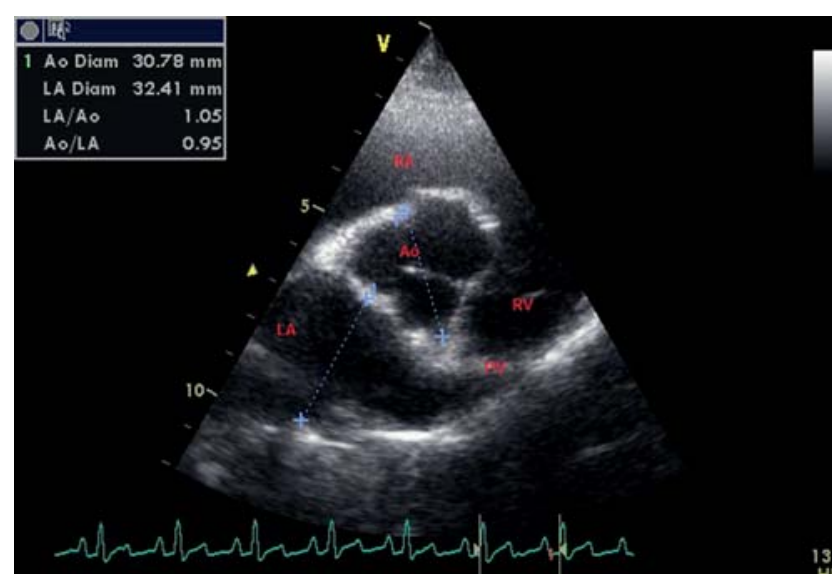

Figuur 2. Dwarse doorsnede op 2D-echocardiografie ter hoogte van de aortaklep van een normaal individu (RV: rechterventrikel - LA: linkeratrium - RA: rechteratrium - Ao: aortaklep - PV: pulmonalisklep).

LVOT volledig. Tegenwoordig gebeurt de classificatie ook op basis van de informatie verkregen door echocardiografie.

Muna et al. (1978) bestudeerden de ultrastructuur van het fibreus weefsel aanwezig bij newfoundlands met SAS. Ze vonden opeenvolgend een endotheellaagje, een enkele laag dens fibreus weefsel en mucopolysacchariden, een elastisch membraan en een onderliggende bindweefsellaag. Het is opmerkelijk dat er geen gelijkmatige densiteit van die bindweefsellaag is over de volledige oppervlakte van het weefsel. De cytologie van de bindweefsellaag is eveneens niet eenduidig. Lichtmicroscopisch herkent men niet alleen fibroblasten, maar ook chondrocytaardige cellen en intermediaire celtypes. Deze cellen zouden allemaal hun oorsprong vinden in primitieve mesenchymale cellen.

\section{ETIOLOGIE VAN SUBAORTASTENOSE: EEN ER- FELIJK DEFECT}

Sinds de jaren ' 70 van de vorige eeuw is reeds bekend dat SAS een erfelijke aandoening is bij de newfoundland. Pyle et al. (1976) haalden een autosomaal dominante overerving met modificerende genen aan als meest waarschijnlijk overervingstype. Ze trokken deze conclusie aan de hand van een aantal testkruisingen. Tegenwoordig wordt algemeen aangenomen dat het gaat om autosomaal dominante overerving met variabele penetrantie (Padgett, 1998; Peelman, 2009), hoewel polygenische overerving nooit kon worden uitgesloten (Kienle, 1998). Het gen (of genen) verantwoordelijk voor SAS bij de newfoundland of de hond in het algemeen is nog niet bekend; wel schuiven Hyun et al. (2006) een aantal kandidaat-genen naar voor in verband met erfelijke hartdefecten bij hond en kat. Eén ervan is het Egfr, het Epidermal growth factor receptor gen, dat verantwoordelijk is voor de expressie van de gelijknamige receptor. Het $E g f r$ is verantwoordelijk voor de ontwikkeling van de semilunaire kleppen. Het homozygoot zijn voor het allel Egfrwaz 


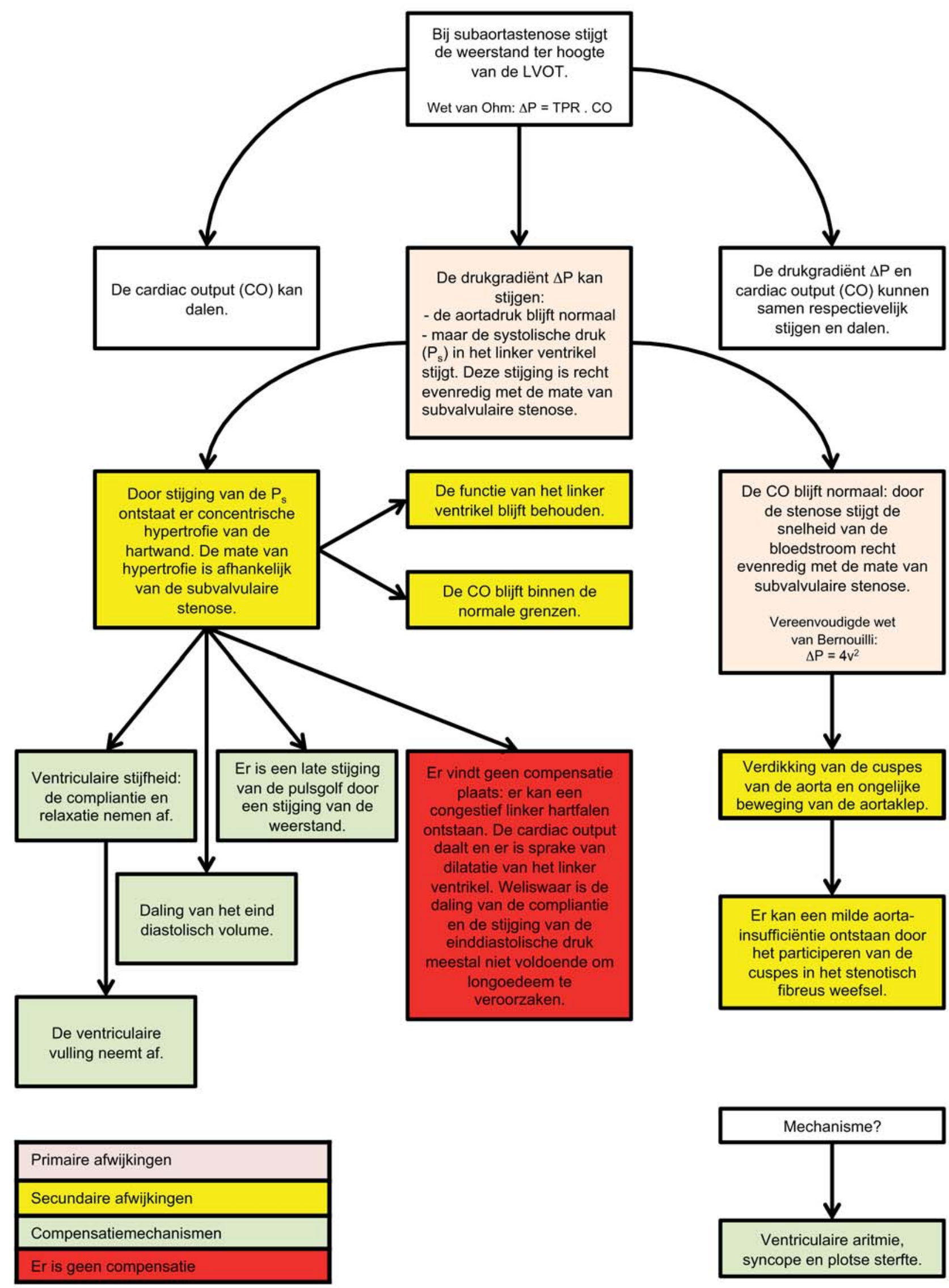

Figuur 3. Pathofysiologie van subaortastenose (Naar Kienle, 1998) (LVOT: linker ventriculaire uitstroomtractus $-\Delta P P$ : drukgradiënt - TPR: totale perifere weerstand - CO: cardiac output - $\mathbf{P}_{\mathrm{S}}$ : systolische druk). 
(waved-2) resulteert bij muizen in een verdikking van de kleppen door een teveel aan mesenchymale cellen. Egfrwa2 codeert voor een mutant proteïne dat slechts 10 tot $20 \%$ van de oorspronkelijke kinaseactiviteit bezit. Volgens Chen et al. (2000) gaat het over een interactie tussen het Egfr en Proteine tyrosine phosphatase non receptor 11 (Ptpn 11), dat codeert voor het proteïne-tyrosine-fosfatase Shp2. De penetrantie voor de defecten bij muizen $E g f r^{w a 2 / w a 2}$ zou worden versterkt door het heterozygoot zijn voor een mutatie in het exon 2 van Ptpn 11 (Egfr wa2/wa2:Ptpn 11 $\left.{ }^{+/}\right)$. Homozygoten Ptpn 11 ${ }^{-/}$ hebben ernstige defecten en sterven tijdens de dracht of binnen de eerste drie levensweken. Het Shp2 zou nodig zijn voor de signaaltransductie van Egfr in vivo. Cardiologisch onderzoek geeft aan dat de muizen, afhankelijk van de gebruikte muizenlijn, in mindere of meerdere mate aortastenose en -regurgitatie ontwikkelen. De aangetaste muizen vertonen eveneens tekenen van huid- en haarabnormaliteiten. Dit mechanisme doet dienst als model voor aortastenose bij de mens.

\section{PATHOFYSIOLOGIE VAN SUBAORTASTENOSE}

De basis voor de pathofysiologie van SAS is de nieuwe weerstand ter hoogte van het linkerventrikel door de obstructie van de LVOT. De wet van Ohm zegt dat de drukgradiënt gelijk is aan het product van de totale weerstand en de cardiac output. Deze totale weerstand is de som van de totale perifere weerstand en de nieuwe weerstand afkomstig van de obstructie van de LVOT. Door de drukgradiënt over de nieuwe weerstand neemt de systolische druk toe. Hierdoor ontwikkelt zich een concentrische hypertrofie van het hart, die recht evenredig kan toenemen met de mate van stenose. Naast deze concentrische hypertrofie ontstaat er ook een snellere bloedstroom ter hoogte van de LVOT met een verdikking en ongelijke beweging van de cuspes van aortaklep tot gevolg. Figuur 3 geeft de pathofysiologie schematisch weer volgens Kienle (1998). De concentrische hypertrofie is een compensatiemechanisme voor de gestegen $\mathrm{P}_{\mathrm{S}}$ en het is derhalve niet ondenkbaar dat bij een meer ernstige graad van SAS met de daarbij horende hogere waarde voor $\mathrm{P}_{\mathrm{S}}$, de hyper- trofie van het linkerventrikel eveneens grotere proporties aanneemt (Kienle, 1998).

Oyama en Thomas (2002) bekijken dit vanuit een andere invalshoek. Volgens hun onderzoek correleert de mate van concentrische hypertrofie slecht met de ernst van de stenose. De vraag stelt zich wat de waarde is van deze parameter in de classificatie van SAS. De concentrische hypertrofie die als compensatie voor de gestegen $\mathrm{P}_{\mathrm{S}}$ wordt verkregen (Figuur $4 \mathrm{a}$ en $4 \mathrm{~b}$ ) is volgens hun bronnen immers afhankelijk van een reeks erfelijke factoren. Bij de mens is er zelfs sprake van een hogere mate van concentrische hypertrofie bij de man. Het polymorfisme van het gen dat codeert voor angiotensine II zou hier een belangrijke rol spelen. Angiotensine II is immers een stimulator van de myocardiale groei. Bij de mens is bekend dat inserties (I) en deleties (D) in het gen hun invloed hebben. D/D polymorfisme zou een grotere kans maken op sterkere concentrische hypertrofie van het linkerventrikel dan I/D of I/I polymorfismen. De mate van concentrische hypertrofie heeft dan ook weer haar invloed op de rest van het ziekteverloop. Kienle (1998) stelt dat concentrische hypertrofie van het linkerventrikel de cardiac output garandeert en dat het einddiastolisch volume slechts laat in de ontwikkeling van de ziekte wordt aangetast. Vindt compensatoire concentrische hypertrofie niet of onvolledig plaats, dan kan een congestief linkerhartfalen ontstaan. SAS leidt echter zelden tot linkerhartfalen. O'Grady et al. (1989) beschrijven longoedeem enkel bij de gelijktijdige aanwezigheid van SAS en mitralisinsufficiëntie.

Het mechanisme verantwoordelijk voor de syncopes en plotse dood is nog niet volledig bekend. Omwille van de vernauwing van de LVOT stellen O'Grady et al. (1989) dat de normale situatie, waarbij de cardiac output bij toegenomen inspanning stijgt onder invloed van fysiologische stimuli, wordt belemmerd. De consequenties zijn dat de spieren en de hersenen onvoldoende bloed en zuurstof toebedeeld krijgen. Dit is de reden waarom er respectievelijk zwaktes en syncopes kunnen ontstaan. Anderzijds zou de syncope ook kunnen ontstaan door de stimulatie van de drukreceptoren in het linkerventrikel. Er ontstaat een valsalvamanoeuvre met

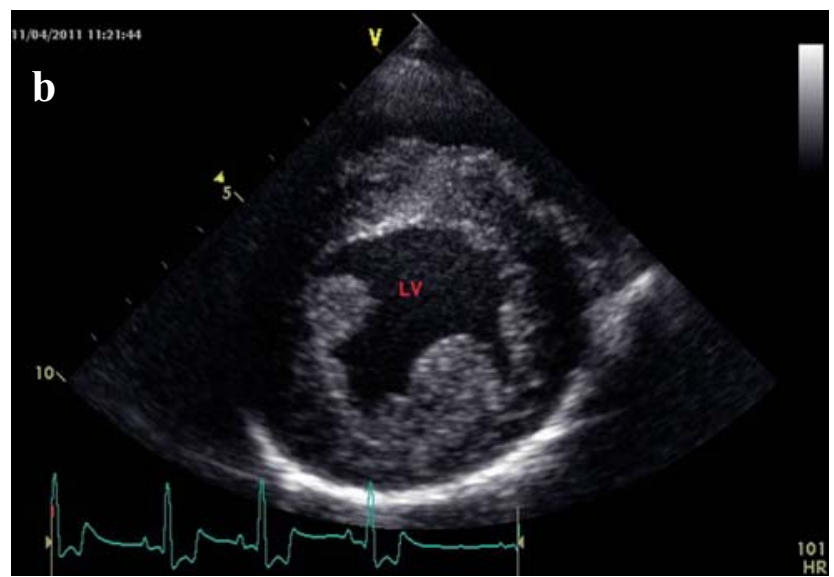

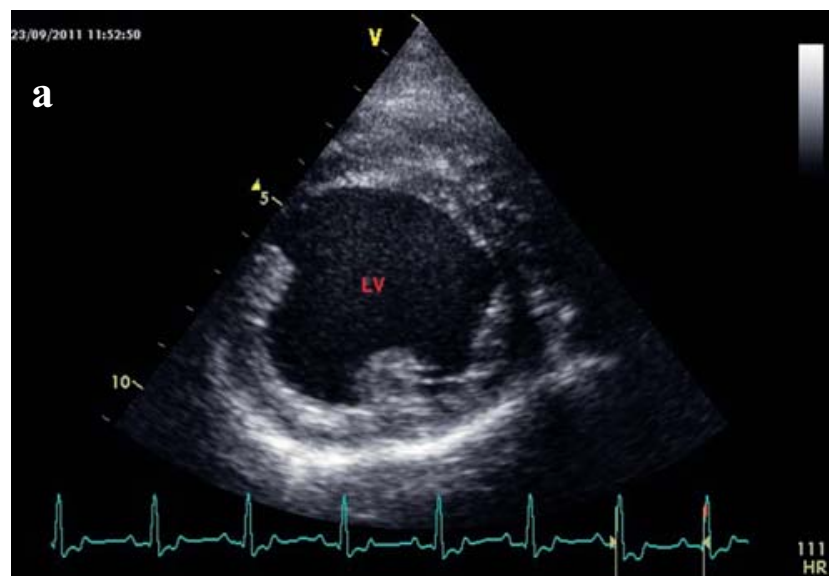

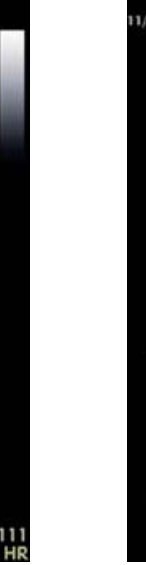

Figuur 4. De echocardiografische $B$-mode beelden van een subaortastenosevrije newfoundland (a) en een newfoundland met matige subaortastenose (b). Bemerk de concentrische hypertrofie: de wanden van het linkerventrikel op $4 \mathrm{~b}$ zijn veel dikker dan op 4a (LV: linkerventrikel). 
bradycardie en vasodilatatie. Ventriculaire aritmieën volgen secundair op de myocardiale ischemie en fibrose (O'Grady et al., 1989), met mogelijk plotse sterfte tot gevolg. Naast hypertrofie van het myocard speelt ook de vernauwing van de intramyocardiale arteries een rol bij de ischemie van het myocard (Falk et al., 2004). Ventriculaire aritmieën leiden tot een daling van het slagvolume en op die manier steeds erger wordende zwaktes en syncopes. Muna et al. (1978) sommen de letsels op die kunnen voorkomen ter hoogte van de intramyocardiale arteries: het vernauwen van het lumen, spiercelproliferatie, hypertrofie van de tunica media, stoornissen in de organisatie van de tunica media met verlies of afwezigheid van de lamina elastica interna.

Bacteriële/infectieuze endocarditis ter hoogte van de aortaklep is een mogelijke complicatie van SAS. Infectieuze endocarditis ontstaat wanneer het bedekkende endotheel schade heeft opgelopen door de hoge snelheid en druk van de bloedstroom, als gevolg van de subvalvulaire stenose. De beschadigde endotheelcellen komen los van de wand en de bacteriën kunnen zich vasthechten aan het fibrine dat zich op de subendotheliale laag heeft vastgehecht. De letsels komen specifiek voor ter hoogte van de oorsprong van de linker coronaire arterie, het ventriculaire deel van de anterieure cuspis van de mitralisklep en het subaortaal gelegen membraan. Focale necrose van de linkerpapillairspier kan ook worden gezien. Histologisch kunnen ontstekingscellen, grampositieve cocci en necrotisch celmateriaal worden onderscheiden. (Muna et al., 1978; O'Grady, 1989).

\section{DIAGNOSE VAN SUBAORTASTENOSE}

\section{Anamnese}

Het grote probleem bij SAS is de afwezigheid van klinische tekenen bij pups, bij de meeste dieren met een milde tot matige stenose, of zelfs bij sommige dieren met een ernstige graad van stenose. Een voorgeschiedenis van bijgeruis kan een aanwijzing zijn. Zeer ernstig aangetaste honden kunnen inspanningsintolerantie vertonen en aangeboden worden met syncope of in zeldzame gevallen met een congestief linkerhartfalen. Plotse sterfte zonder voorafgaande klinische tekenen is eveneens mogelijk bij SAS (Kienle, 1998 en Ware, 2007).

\section{Lichamelijk onderzoek}

Bij auscultatie van patiënten met SAS kan een holosystolisch bijgeruis gehoord worden (MacDonald, 2006). O'Grady et al. (1989) benadrukken dat niet bij alle honden met SAS een holosystolisch bijgeruis gehoord kan worden, daar zeer milde obstructies slechts een bijgeruis teweegbrengen gedurende het eerste derde van de systole. Kienle (1998) benadrukt dat de intensiteit van het bijgeruis grotendeels overeenstemt met de ernst van de obstructie. Bij honden met een milde graad van stenose gaat het over bijgeruisen van graad I tot III/VI, bij honden met een ernstige graad van stenose over graad IV tot V/VI. Aangezien de obstructie zich geleidelijk aan ontwikkelt, kan het bijge- ruis ook toenemen in intensiteit gedurende de eerste levensmaanden. MacDonald (2006) bevestigt dat de intensiteit correleert met de mate van stenose, maar zij heeft het slechts over een ruwe schatting. De vorm van het bijgeruis is crescendo-decrescendo. Het klinkt bij milde gevallen muzikaal, in tegenstelling tot de meer schurende bijgeruisen bij ernstige gevallen (O'Grady et al., 1989). Het systolisch bijgeruis is gewoonlijk het luidst ter hoogte van de hartbasis links (Kienle, 1998). Het uitstralen van het bijgeruis is erg karakteristiek voor SAS. Het geluid wordt waarneembaar ter hoogte van de apex links en bij erge gevallen over de rechterthoraxwand en over de arteria carotis (Kienle, 1998 en MacDonald, 2006). Naast het systolisch bijgeruis te wijten aan SAS, kunnen er ook bijgeruisen voorkomen als gevolg van secundaire veranderingen. Zo kan er bij aorta-insufficiëntie een diastolisch bijgeruis voorkomen ter hoogte van de hartbasis links (Kienle, 1998). O'Grady et al. (1989) stellen echter dat het diastolisch bijgeruis meestal niet wordt waargenomen door de te lage frequentie. Behalve aorta-insufficiëntie kan ook mitralisinsufficiëntie een (holo)systolisch bijgeruis veroorzaken. Het punctum maximum situeert zich dan eerder ter hoogte van de apex links, metradiatie naar de hartbasis bij luidere bijgeruisen. De mogelijkheid bestaat ook dat er een trilling voelbaar is bij palpatie te wijten aan het intense bijgeruis. Bij honden met een ernstige obstructie van de LVOT kan de pulsgolf hypokinetisch zijn. Als gevolg hiervan kan men ter hoogte van de arteria femoralis een pulsus parvus et tardus waarnemen en de afwezigheid van de jugulaire pols (Kienle, 1998).

\section{Elektrocardiografie}

Alhoewel het elektrocardiogram meestal normaal is bij patiënten met SAS, kan het toch nuttig zijn als diagnostisch middel. Theoretisch kunnen tekenen aanwezig zijn van hypertrofie van het linkerventrikel, zoals een vergrote R-golf in afleidingen II en aVF, een verlengd QRS-complex en/of veranderingen in het STsegment (O'Grady et al., 1989; Kienle, 1998). De veranderingen in het ST-segment zijn indicatief voor ischemie van het myocard (O'Grady et al., 1989; Kienle, 1998; MacDonald, 2006). Het spreekt voor zich dat wanneer er gelijktijdig andere aandoeningen voorkomen het elektrocardiogram anders moet worden geïnterpreteerd. Zo wijst O'Grady (1989) erop dat wanneer er gelijktijdig sprake is van mitralisinsufficiëntie de bovengenoemde tekenen wel vaak voorkomen maar dan eerder in het kader van een dilatatie dan van hypertrofie van het linkerventrikel.

\section{Radiografie van de thorax}

Bij individuen met een ernstige graad van stenose kan men op radiografie een milde cardiomegalie waarnemen als gevolg van concentrische hypertrofie van het linkerventrikel en een dilatatie van de aorta of een verbreding van het mediastinum door de poststenotische dilatatie van de aorta. Deze dilatatie van de aorta ascendens ontstaat als gevolg van de turbulentie van het 
bloed na stenose. Bij milde gevallen is er meestal niets te zien op radiografie (Kienle, 1998; Ware, 2007).

\section{Echocardiografie}

Echocardiografie is het belangrijkste middel van de dierenarts om tot de diagnose en de daaruit volgende prognose van SAS te komen. Er kan gebruik worden gemaakt van de brightness-mode (B-mode) echocardiografie, de motion-mode (M-mode) echocardiografie en de dopplerechocardiografie. Om de LVOT te kunnen beoordelen, is het vanzelfsprekend noodzakelijk het normale echografisch beeld van de LVOT goed te beschrijven. Hierna wordt ingegaan op enkele specifieke echocardiografische parameters die van toepassing zijn bij SAS.

\section{B-mode echocardiografie en dopplerechocardiografie}

De $B$-mode wordt gebruikt om een tweedimensionaal (2D) beeld te krijgen. Dopplerechografie wordt gebruikt om de beweging van het bloed te detecteren. Pulsed wave Doppler (PWD) kan metingen uitvoeren op een welbepaalde plaats maar is niet in staat om hoge snelheden waar te nemen. Continuous wave Doppler (CWD) daarentegen kan hoge snelheden meten maar het is niet exact te bepalen op welke plaats wordt gemeten. Vooral de CWD wordt in de cardiale echografie gebruikt. De kleurendoppler (KD) detecteert de beweging van het bloed en de richting waarin het stroomt. Er wordt gebruik gemaakt van een kleurschaal: rood voor bloedstroom naar de sonde toe, blauw voor bloedstroom van de sonde weg en turbulentie wordt met groen aangegeven. De kleuren worden vervolgens gesuperponeerd over de $B$-mode (Ware, 2007). Het is aan te raden de standaard parasternale overlangse doorsnede (Figuur 5) en de standaard parasternale dwarse doorsnede van rechts uit te bekijken en de apicale 4- en 5-kamerbeelden langs de linkerzijde te bekijken. Op die manier kan men op een 2D-beeld de LVOT het beste beoordelen.

Voor de rechter parasternale overlangse doorsnede

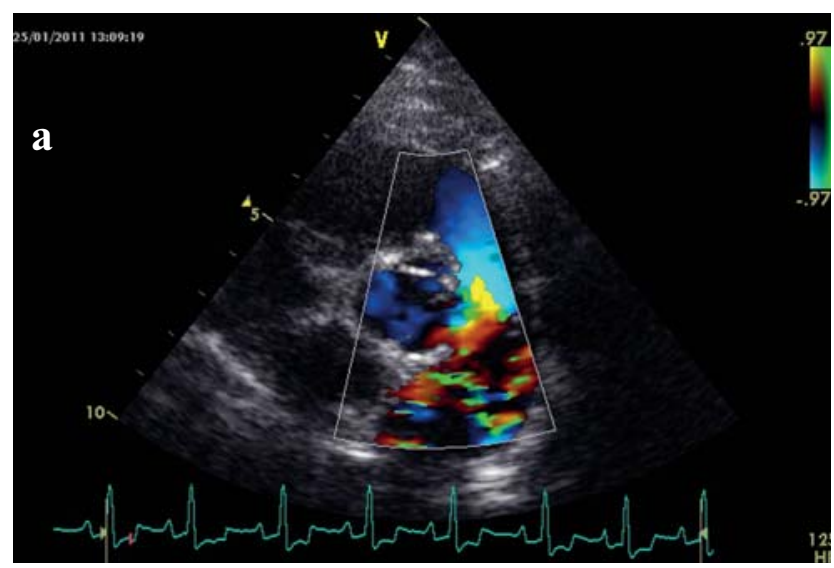

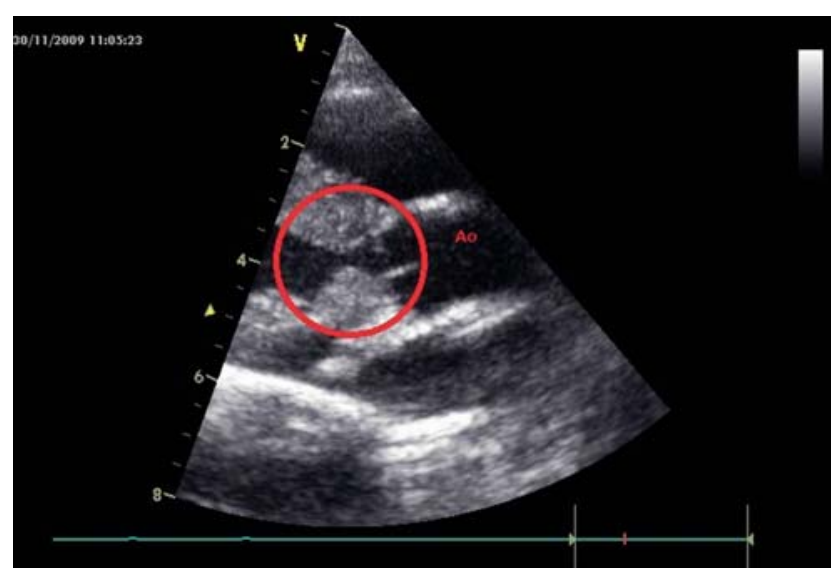

Figuur 5. Overlangse doorsnede (B-mode) van de linker ventriculaire uitstroomtractus (LVOT) bij een newfoundlandpup met milde subaortastenose. De normale kegelvorm van de LVOT is verloren gegaan door het fibreus weefsel net onder de aortaklep (rode cirkel) (Ao: aorta).

adviseren Bussadori et al. (2000) de KD om zo de systolische turbulentie ter hoogte van de subvalvulaire regio te kunnen waarnemen. Op 2D kan ook de mate van vernauwing worden nagegaan. Normaal worden de oppervlakten van de LVOT op dwarse doorsnede progressief kleiner naar de aorta toe. Is dit niet het geval en is er sprake van een abrupte vernauwing ter hoogte van de subvalvulaire regio, dan kan er sprake zijn van een subvalvulaire aortastenose. Bussadori et al. (2000) wijzen er eveneens op dat men op dit beeld ook dopplermetingen kan uitvoeren om de rechter ventriculaire uitstroomtractus te inspecteren, omdat pulmonalisstenose in een aantal gevallen geassocieerd is met SAS (Figuur 6).

De linker apicale 4- en 5-kamerbeelden kunnen eveneens worden gebruikt ter beoordeling van SAS. PWD wordt gebruikt bij het 4-kamerbeeld om de snelheid van de diastolische vulling in beide ventrikels te controleren. Deze diastolische vulling kan sterk bemoeilijkt worden door de concentrische hypertrofie die resulteert in verhoogde stijfheid van de hartspier. PWD en CWD kunnen beide worden gebruikt om na te gaan of er regurgitatie optreedt tijdens de systole ter

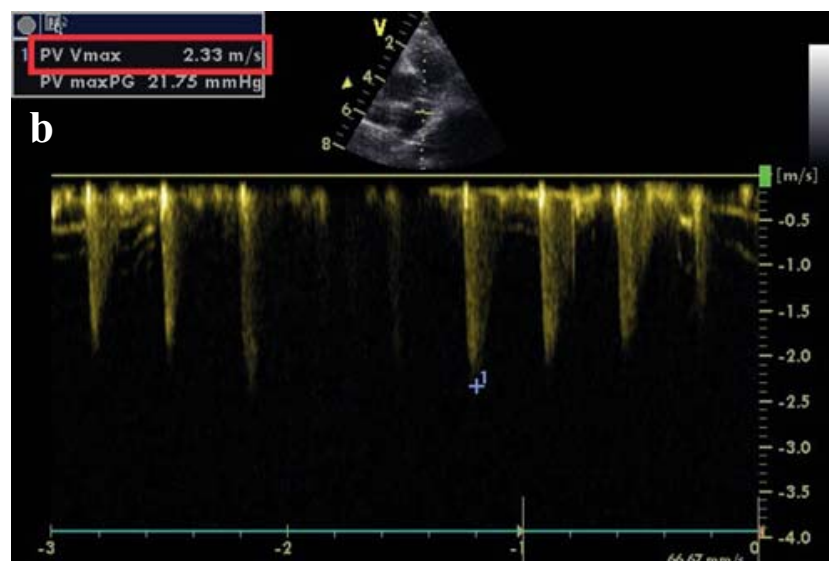

Figuur 6. Pulmonalisstenose bij een newfoundlandpup met eveneens milde subaortastenose. (a) De kleurendoppler geeft duidelijk turbulentie aan ter hoogte van de pulmonalisklep (groene kleur). (b) De algemeen aanvaarde maximumwaarde voor de bloedsnelheid ter hoogte van de pulmonalisklep $(1,5 \mathrm{~m} / \mathrm{s})$ is hier overschreden $(2,33 \mathrm{~m} / \mathrm{s})$ (continuous wave doppler). 


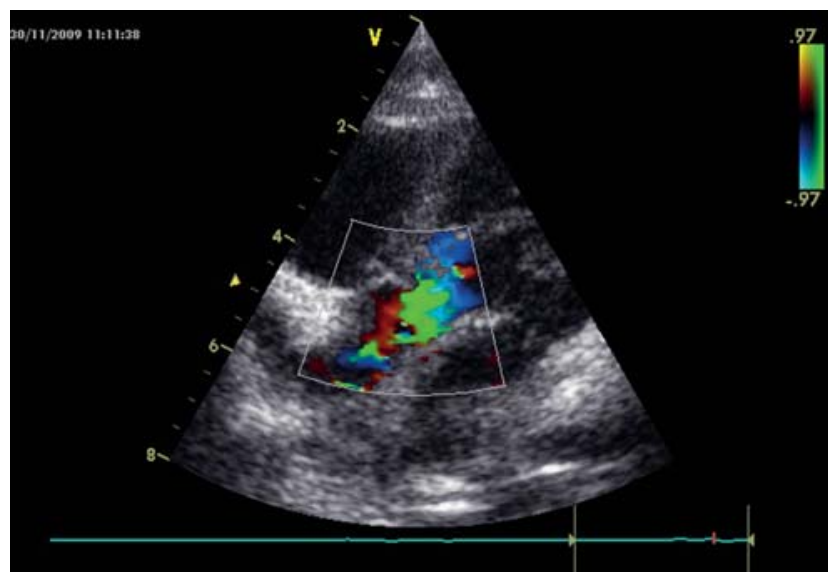

Figuur 7. Turbulentie (groene kleur) ter hoogte van de aortaklep met behulp van kleurendoppler bij een newfoundlandpup met milde subaortastenose (linker apicaal 5-kamerbeeld) (kleurendoppler) (RV: rechterventrikel - LV: linkerventrikel - LA: linkeratrium - Ao: aorta).

hoogte van de mitralis- en tricuspidaliskleppen, ten gevolge van de gestegen druk door de stenose. Hiervoor kan ook KD worden aangewend. De linker apicale 5 -kamerbeelden komen in aanmerking om de LVOT te beoordelen in B-mode. De drie Doppler-modes moeten worden aangewend op het 5-kamerbeeld om de stenose (Figuur 7) en de eventuele aortainsufficiëntie te diagnosticeren (Bussadori et al., 2000). Naast de bovengenoemde standaardopnamen is het ook mogelijk de sonde subcostaal te plaatsen. De patiënt wordt hiervoor het beste in rechterzijlig geplaatst. Er kan gebruik gemaakt worden van PWD en CWD (Bussadori et al., 2000). De snelheden die worden gemeten met de sonde in subcostale positie zijn betere schattingen dan met de standaardopnamen. Dit komt omdat de geluidsgolven die voortkomen uit de sonde zo parallel mogelijk verlopen met de bloedstroom. Hoe groter de hoek tussen de geluidsgolven en de bloedstroom, hoe sterker de bloedsnelheid wordt onderschat (Riesen et al., 2007).

\section{M-mode echocardiografie}

De M-mode echocardiografie wordt gebruikt om bewegingen in de tijd in beeld te brengen (Ware, 2007). In milde tot erge gevallen van SAS is de concentrische hypertrofie van het linkerventrikel, net als bij de 2Dechocardiografie, het meest opvallend. De dikte van het interventriculaire septum tijdens de diastole (IVSd) en de dikte van de linker ventriculaire vrije wand (LVPWd) kunnen sterk zijn toegenomen (Figuur 8). Bij $M$-mode echocardiografie is het eveneens mogelijk de diameter van het linkerventrikel te meten op het einde van de diastole (LVIDd) en systole (LVIDs) (Oyama en Thomas, 2002).

\section{Echocardiografische parameters bij subaortastenose}

Naast de detectie van de eigenlijke stenose ter hoogte van de LVOT, zoals hierboven bij de specifieke echocardiografische modes vermeld, kan nog een hele reeks andere echografische abnormaliteiten worden waargenomen. Kienle (1998) en Ware (2007) noemen onder andere de poststenotische dilatatie van de ascenderende aorta, de secundaire verdikking van de aortakleppen en de sluiting van de aortakleppen in het midden van de systole. De poststenotische dilatatie kan worden gezien vanuit de rechter overlangse doorsnede maar nog beter vanuit de linker overlangse doorsnede. De secundaire verdikking van aortakleppen is het gevolg van microtraumata ter hoogte van de kleppen door de zogenaamde jets veroorzaakt door de stenose. Er is eventueel ook sprake van ischemische fibrose die zichtbaar wordt als een hyperechogene zone ter hoogte van de papillairspieren of het subendocard van het linkerventrikel.

Dopplerechocardiografie is een onmisbaar diagnostisch middel bij milde gevallen van SAS. Wanneer er geen duidelijke abnormaliteiten zichtbaar zijn op het 2D-beeld kan het bijvoorbeeld toch zijn dat KD regurgitatie aangeeft ter hoogte van de aortaklep. Dit is een zeer belangrijke diagnostische parameter bij milde
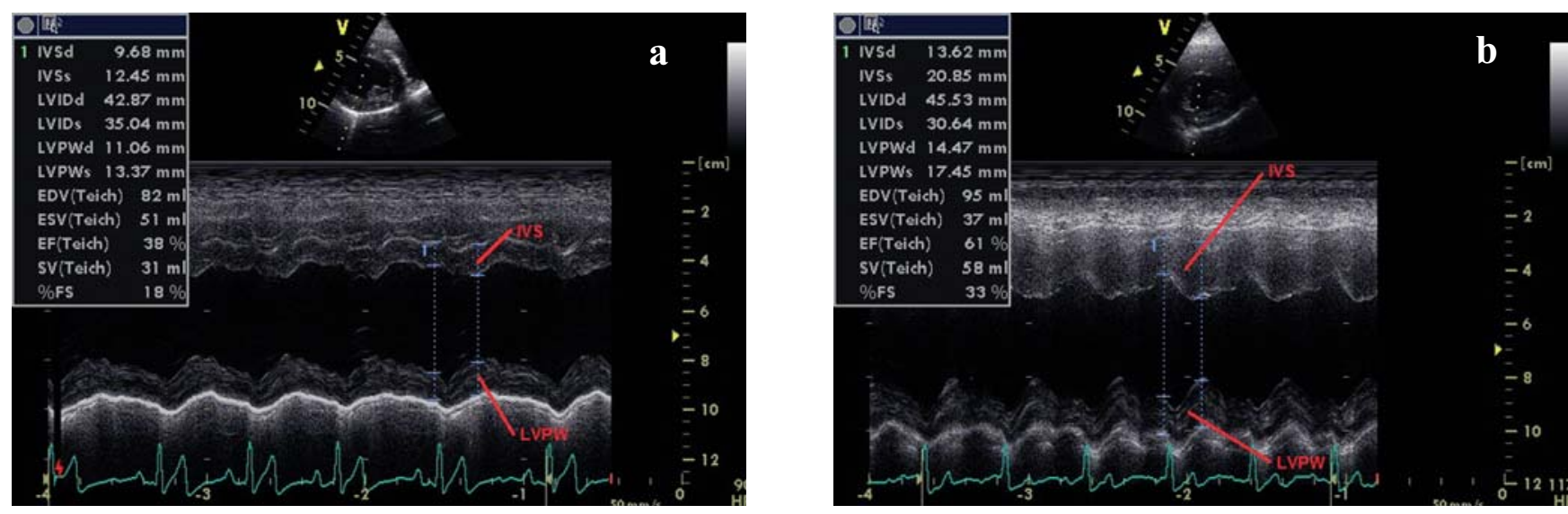

Figuur 8. De vergelijking tussen een subaortastenosevrije newfoundland (a) en een newfoundland met matige subaortastenose (b) op basis van M-mode echocardiografie. Bemerk de concentrische hypertrofie: het interventriculaire septum (IVS) en de vrije wand van het linkerventrikel (LVPW) zijn duidelijk dikker bij $8 b$. 
Tabel 1. Classificatie van subaortastenose naargelang de drukgradiënt $\Delta p$ en de snelheid van de bloedstroom gemeten over de aortaklep (Naar Bussadori et al., 2000).

\begin{tabular}{lcc}
\hline & $\begin{array}{c}\text { Drukgradiënt } \Delta \mathbf{P} \\
\text { in } \mathbf{~ m} \mathbf{m g}\end{array}$ & $\begin{array}{c}\text { Snelheid van de } \\
\text { bloedstroom in } \mathbf{~ m} / \mathbf{s e c}\end{array}$ \\
\hline Geen stenose & $<18$ & $<2.00$ \\
Verdacht & $\geq 18-<20$ & $\geq 2,00-<2,25$ \\
Milde stenose & $\geq 20-<50$ & $\geq 2,25-<3,50$ \\
Matige stenose & $\geq 50-<80$ & $\geq 3,50-<4,50$ \\
Ernstige graad van stenose & $\geq 80$ & $\geq 4,50$ \\
\hline
\end{tabular}

Tabel 2. De verhouding oppervlakte LVOT/oppervlakte aorta bij verschillende gradaties van met SAS aangetaste hondenpopulaties (Naar Oyama en Thomas, 2002).

\begin{tabular}{lc}
\hline & $\begin{array}{c}\text { Verhouding } \\
\text { oppervlakte LVOT/oppervlakte aorta }\end{array}$ \\
\hline Normaal individu (zonder SAS) & $0,637+/-0,023$ \\
Milde SAS & $0,656+/-0,034$ \\
Matige SAS & $0,391+/-0,030$ \\
Ernstige graad van SAS & $0,232+/-0,023$ \\
\hline
\end{tabular}

gevallen, want behalve bij SAS komt aortaregurgitatie slechts zelden voor, tenzij bij een ventriculair septumdefect en bij bacteriële endocarditis (Kienle, 1998).

De pieksnelheid van de bloedstroom en het bepalen van de drukgradiënt $\Delta \mathrm{P}$

Door gebruik te maken van de vereenvoudigde wet van Bernoulli, die stelt dat de drukgradiënt gelijk is aan de snelheid in het kwadraat vermenigvuldigd met vier, is het mogelijk uitgaande van de snelheden van de bloedstroom, verkregen door de dopplerechocardiografie, de drukgradiënt $\Delta \mathrm{P}$ te bepalen tussen linkerventrikel en aorta. Er wordt gebruik gemaakt van een classificatiesysteem om de mate van SAS aan te duiden (Tabel 1) (Figuur 9 en 10). Wanneer de pieksnelheden van de bloedstroom ter hoogte van de LVOT worden gemeten, stelt Kienle (1998) dat er vanaf een pieksnelheid van de bloedstroom over de aorta van 2,0 $\mathrm{m} / \mathrm{s}$, gemeten vanuit het linker apicale 5-kamerbeeld,

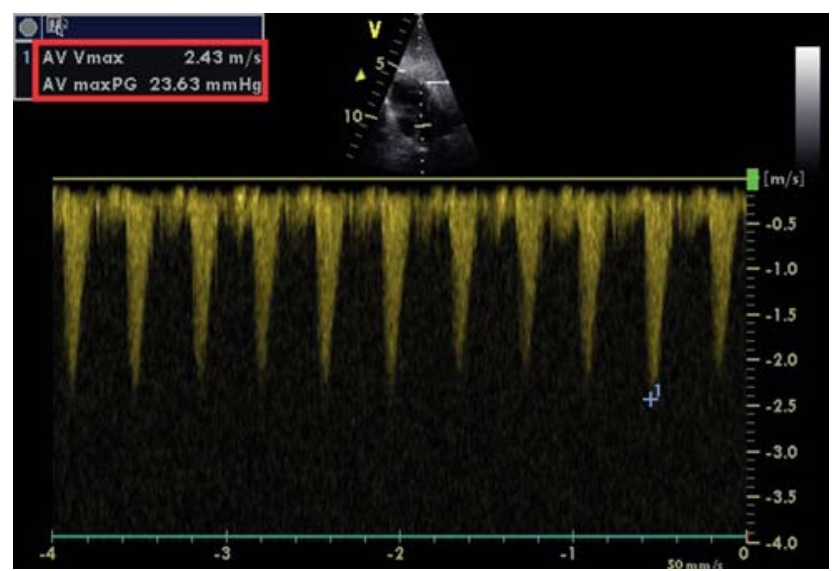

Figuur 9. Een pieksnelheid van $2,43 \mathrm{~m} / \mathrm{s}$ en een drukgradiënt van 23,63 mmHg. Er is sprake van een milde subaortastenose (continuous wave doppler). gesproken kan worden van een te hoge snelheid, hoewel bij niet-aangetaste individuen zelfs pieksnelheden van meer dan $1,7 \mathrm{~m} / \mathrm{s}$ maar zelden voorkomen (Ware, 2007).

De verhouding oppervlakte LVOT/oppervlakte aorta

Door middel van de rechter parasternale dwarse doorsnede wordt de LVOT tijdens de diastole in beeld gebracht ter hoogte van de subvalvulaire regio. De aorta wordt tijdens de diastole op dezelfde manier in beeld gebracht maar dan ter hoogte van de sinussen van Valsalva. De verhouding van beide oppervlakten kan vervolgens worden berekend. Oyama en Thomas (2002) controleerden deze parameter in een onderzoek. De resultaten worden vermeld in Tabel 2 .

Naargelang de stenose erger wordt, moet de verhouding normalerwijze dalen; de doorgang van de LVOT en dus ook de dwarse oppervlakte die hier wordt gemeten, worden immers steeds kleiner. Normale in-

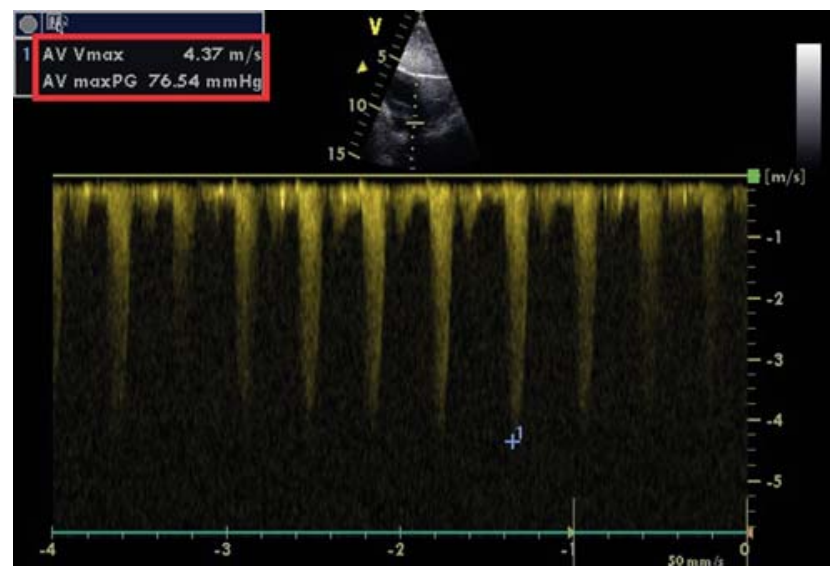

Figuur 10. Een pieksnelheid van $4,37 \mathrm{~m} / \mathrm{s}$ en een drukgradiënt van $76,54 \mathrm{mmHg}$. Er is sprake van een matige subaortastenose (continuous wave doppler). 
dividuen hebben echter ook een lagere ratio dan de mild aangetaste honden. Oyama en Thomas (2002) wijten dit aan toeval en besluiten dat er geen verschil in ratio waar te nemen is tussen normale en mild aangetaste honden. Samengevat wijst een verhouding bij aangetaste honden van meer dan 0,5 op milde SAS, een verhouding tussen 0,5 en 0,3 op matige SAS en een verhouding van minder dan 0,3 op een ernstige graad van SAS.

Het berekenen van de oppervlakte ter hoogte van de stenose

Estrada en Maisenbacher (2006) stellen dat parameters, zoals de bloedsnelheid en de $\Delta \mathrm{P}$ die daaruit kan worden berekend (cf. Bernoulli), niet steeds betrouwbaar zijn. Bepaalde factoren, zoals anesthesie, sedatie en myocardinsufficiëntie, verminderen de cardiac output en leiden bijgevolg tot een onderschatting van de drukgradiënt en de bloedsnelheid. Het tegengestelde is waar voor stress, pijn, koorts, ... die een verhoogde cardiac output veroorzaken. Om die reden stellen zij voor de effectieve oppervlakte van de stenotische ring te bepalen. Deze effectieve oppervlakte kan eenvoudig worden bekomen met een echotoestel.

\section{Katheterisatie van het hart}

Deze techniek wordt nog zelden toegepast. Kienle (1998) legt uit dat door middel van cardiale katheterisatie de drukgradiënt $\Delta \mathrm{P}$ kan worden gemeten. De druk wordt gemeten terwijl de katheter geleidelijk aan wordt teruggetrokken vanuit het linkerventrikel over de subvalvulaire regio tot in de aorta. In vergelijking met de drukbepalingen bekomen door echocardiografie is de drukgradiënt $\Delta \mathrm{P}$ hier steeds een stuk kleiner door het gebruik van algemene anesthetica.

\section{PROGNOSE VAN SUBAORTASTENOSE}

De prognose van SAS is afhankelijk van de ernst van de stenose, de leeftijd en het gebruiksdoel van de hond. De graad van subaortastenose geeft daarenboven geen eenduidig klinisch beeld. Bij een ernstige graad van SAS bijvoorbeeld kan er omwille van de depressie van de cardiac output, enkel een beeld van inspanningintolerantie worden geobserveerd. Bij andere patiënten met een ernstige graad van SAS is er dan weer sprake van aritmieën en plotse sterfte (O'Grady et al., 1989). Afhankelijk van het gebruiksdoel van de hond komt de inspanningintolerantie meer of minder tot uiting. De prognose is bijgevolg slechter voor een newfoundland die ingezet wordt voor waterwerk, dan voor een newfoundland die als gezelschapsdier wordt gehouden. De plotse dood vindt volgens Kienle (1998) plaats bij $70 \%$ van de dieren met een ernstige graad van SAS en op een gemiddelde leeftijd van 14,4 maanden. Bij een milde graad van SAS zijn de levensverwachtingen normaal en komen er meestal geen symptomen tot uiting. Wanneer er niet wordt behandeld, kan de prognose van patiënten met milde tot matige SAS nog worden bestempeld als gereserveerd tot goed. Voor patiënten met een ernstige graad van SAS die niet behandeld worden, is de prognose uitermate slecht. Het is van belang te benadrukken dat SAS een progressieve aandoening is tot op een leeftijd van 18 maanden. De prognose is bijgevolg sterk afhankelijk van de leeftijd. Het is dus vanzelfsprekend dat een volwassen hond met een milde graad van SAS een betere prognose heeft dan een pup van enkele weken oud met een milde graad van SAS.

Complicaties, zoals infectieuze endocarditis en linkerhartfalen, zijn zeldzaam en komen slechts voor wanneer de patiënt lang genoeg leeft, met name bij dieren met een milde tot matige graad van SAS. Linkerhartfalen op jonge leeftijd komt in het bijzonder voor bij honden die naast SAS ook lijden aan congenitale mitralisdysplasie (Kienle, 1998).

Naast de prognose inzake de levenskwaliteit en -duur, kan ook de prognose met betrekking tot het fokken worden nagegaan.

\section{FOKADVIES}

Gebaseerd op de bovenstaande literatuurgegevens kan worden geprobeerd een gepast fokadvies op te stellen. Fokadvies is afhankelijk van een aantal factoren. Ze kunnen worden onderverdeeld in factoren die eigen zijn aan de aandoening (ziektefactoren) en aan het dier zelf (dierfactoren).

\section{Ziektefactoren}

Onder ziektefactoren worden de prevalentie, het overervingspatroon en het ziekteverloop verstaan. Elke van deze drie factoren heeft een duidelijke invloed op de aanpak van dit probleem. De prevalentie van SAS is niet precies bekend, maar het is wel duidelijk dat deze aandoening meer dan sporadisch voorkomt. Om een goed fokadvies te kunnen geven, zouden niet enkel globale prevalentiecijfers nodig zijn, maar ook specifieke geografische prevalentiecijfers. Algemeen kan men echter stellen dat SAS in die mate voorkomt dat het mogelijk moet zijn de aangetaste dieren uit de fok te weren.

Het overervingspatroon van SAS is nog steeds een discussiepunt. Uitgaande van de algemeen aanvaarde hypothese van een dominant overervingspatroon met variabele penetrantie, kan het beste het volgende worden geadviseerd. Honden waarvan men zeker is dat ze aangetast zijn, kunnen uit de fok worden geweerd. Het feit dat men hier te maken heeft met variabele penetrantie bemoeilijkt echter het onderkennen van de ziekte. Om die reden is het niet ondenkbaar dat er in de praktijk wordt gefokt met dragers zonder dat men er weet van heeft. Het fokadvies bestaat er hier in de kynologische wereld ertoe te bewegen een algemeen screeningsprogramma op punt te zetten, waarbij auscultatie en echocardiografie de pijlers vormen.

Het ziekteverloop van SAS heeft zeker ook een belangrijke invloed op het fokadvies. SAS is een progressieve aandoening die kan evolueren tot de leeftijd 
van 18 maanden en dus moet de nadruk worden gelegd op het feit dat het screenen maar vanaf deze leeftijd mag gebeuren. Met de mate van stenose mag idealiter geen rekening worden gehouden in het geven van fokadvies. Dit heeft te maken met de variabele penetrantie waarvan uitgegaan wordt. Een mild aangetast ouderdier kan ernstig aangetaste pups geven en omgekeerd.

\section{Dierfactoren}

De dierfactoren omvatten ondermeer de eigenschappen van het individuele dier. Concreet kan het exterieur als voorbeeld genomen worden. Een newfoundland die uitmuntend scoort op een tentoonstelling is moeilijk uit de fok te weren. Er moet bijgevolg een balans worden opgemaakt tussen de gezondheid van de populatie en de individuele motivatie om toch te gaan fokken. Een andere factor is het geslacht. Hier dient te worden opgemerkt dat een reu beduidend meer nakomelingen kan verwekken dan een teef. De praktische bruikbaarheid van deze factor kan echter in vraag worden gesteld. De beste keuze is vanzelfsprekend om noch met een aangetaste teef, noch met een aangetaste reu verder te fokken.

\section{Algemeen fokadvies}

In de praktijk wordt er goed aan gedaan aangetaste honden te weren uit de fok. Indien men toch overweegt om met een hond met SAS te fokken, is het vanzelfsprekend zo dat dit gebeurt met een SAS-vrije partner. Inteelt is hier absoluut tegenaangewezen. Men kan proberen het erfelijk defect uit te fokken door twee ouderdieren te nemen met een verschillende genetische achtergrond. Hiervoor heeft men verschillende mogelijkheden. Er kan worden gefokt tussen rassen die al dan niet met elkaar verwant zijn. In het geval van de newfoundland is dat bijvoorbeeld het sterk verwante ras, de landseer. Of men kan fokken binnen het ras, waarbij men uiteraard twee onverwante individuen beschouwt.

\section{DISCUSSIE}

De pathofysiologie is nog niet voor $100 \%$ bekend. Het voornaamste pijnpunt is de manier waarop syncopes en plotse dood kunnen plaatsvinden. Verschillende hypothesen zijn reeds naar voor geschoven, zoals een zuurstoftekort omwille van de verminderde cardiac output, stimulatie van de drukreceptoren en een vernauwing van de intramyocardiale arteries. Onderzoek moet nog zekerheid brengen. Wat het klinische aspect van SAS betreft, moet eerst duidelijk worden gesteld dat door middel van anamnese, algemeen klinisch onderzoek en adequate hartauscultatie, geen definitieve diagnose kan worden gesteld. Men moet immers rekening houden met de mogelijkheid dat de patiënt geen of slechts zeer milde klinische symptomen kan vertonen. Het is eveneens belangrijk te weten dat auscultatie op zich enkel een differentiaaldiagnose maar geen sluitende diagnose kan opleveren. Om deze redenen moet in de praktijk beroep gedaan worden op echocardiografie. Ook hier moet echter een kanttekening worden gemaakt. De vraag dringt zich op welke de echocardiografische 'normaalwaarden' zijn voor de pieksnelheden van de bloedstroom over de aortaklep. Men is er nog steeds niet uit of echocardiografisch gemeten pieksnelheden tussen 2,0 en 2,25 m/s normaal dan wel pathologisch zijn. Daarom beschouwt men dergelijke patiënten het beste als verdacht. Een adequate opvolging is bijgevolg ten zeerste aanbevolen.

Als conclusie kan dus worden gesteld dat echocardiografie een sterke indicatieve waarde heeft, maar niet $100 \%$ diagnostisch is bij alle patiënten.

Het voorstel van Chen et al. (2000) om het muizenmodel met het $E g f r$-gen als model te nemen voor erfelijke hartaandoeningen kan op verschillende manieren worden ondersteund. Er zijn een aantal gelijkenissen tussen het muizenmodel en SAS bij de newfoundland. Als eerste gelijkenis kan worden vermeld dat het $E g f r$ gen verantwoordelijk is voor de ontwikkeling van de semilunaire kleppen bij de muis. In het bijzonder gaat het hier over de aortakleppen. Bij homozygotie Egfrwaz/wa2 is er een overvloedige aanwezigheid van mesenchymale cellen. Het macroscopisch en histologisch beeld bij SAS kan worden beschouwd als een eerste overeenkomst. De laesies ter hoogte van de LVOT wijzen eveneens op een teveel aan mesenchymaal weefsel. Histologisch is er geen eenduidigheid in de densiteit van de bindweefsellaag en in de cytologische kenmerken van het weefsel. De kraakbenige omvorming van het mesenchymale weefsel zou kunnen worden verklaard door de hogere druk aanwezig in het linkerventrikel bij SAS en door de verminderde mogelijkheid de vele mesenchymale cellen adequaat te kunnen voeden door het proliferatief karakter van de mesenchymale cellen. Het endocardiale weefsel behoudt immers zijn proliferatieve eigenschappen tot enige tijd na de geboorte, evenals de mogelijkheid om zich kraakbenig om te vormen. Een dikkere cellaag is immers moeilijker te voeden.

De tweede overeenkomstige factor is de variabele penetrantie. In het muizenmodel wordt de variabele penetrantie toegeschreven aan een mutatie in het Ptpn11gen. De heterozygote dieren zouden meer kans maken op een ernstige graad van aortastenose. Het onvolledig doorkomen van een erfelijk kenmerk kan veel oorzaken hebben. Wanneer de indeling genetische en niet-genetische (milieu, ...) factoren gehanteerd wordt, kan men gemakkelijk begrijpen dat bij de newfoundland genetische factoren de oorzaak zouden kunnen zijn. In de literatuur is immers nergens beschreven dat bepaalde milieufactoren een invloed hebben op de ontwikkeling van SAS. Men mag hier weliswaar niet te kort door de bocht gaan. Eerst en vooral is het onverstandig dergelijke uitspraken te doen over de mogelijke oorzaken van de variabele penetrantie, anderzijds gaat het in het geval van dit model misschien over een polygenisch overervingstype, waarbij Chen et al. (2000) niet uitgaan van een dominant overervingspatroon van het wa2 allel. Ptpn 11 kan beschouwd worden als een dominant letaal allel. De kruisingen die Pyle et al. in 1976 deden, sluiten in elk geval de mogelijkheid van 
polygenische overerving niet uit. De grens tussen een dominant overervingspatroon met variabele penetrantie en polygene overerving is weliswaar niet duidelijk te trekken. Aangezien Ptpn 11 een letaal allel is, zou het van belang kunnen zijn om de nestgrootte van aangetaste ouderdieren te vergelijken met de nestgrootte van niet-aangetaste ouderdieren. Bij de niet-aangetaste ouderdieren verwacht men gemiddeld grotere nesten.

Naast het algemeen aanvaarde autosomaal dominante overervingstype met variabele penetrantie, is er nog een tweede factor in het nadeel van het muizenmodel. De lokalisatie van de stenose is immers verschillend. Bij de muis gaat het over aortastenose en bij de newfoundland over subaortastenose. Hyun et al. (2005) vermeldden dat de aangetaste muizen eveneens haar- en huidabnormaliteiten hadden. Dit is naast de nestgrootte een tweede parameter die zou moeten worden nagegaan bij de aangetaste newfoundlands. Het ophelderen van het werkelijke overervingspatroon kan in de praktijk zijn nut bewijzen. Het geven van fokadvies zou accurater kunnen gebeuren.

\section{LITERATUUR}

Bussadori C., Amberger C., Le Bobinnec G., Lombard C. W. (2000). Guidelines for the echocardiographic studies of suspected subaortic and pulmonic stenosis. Journal of Veterinary Cardiology 2(2), 17-24.

Chen B., Bronson R. T., Klaman L. D., Hampton T. G., Wang J., Green P., Magnuson T., Douglas P. S., Morgan J. P., Neel B. G. (2000). Mice mutant for Egfr and Shp2 have defective cardiac semilunar valvulogenesis. Nature Genetics 24, 296-299.

Estrada A., Maisenbacher H. (2006). Calculation of stenotic valve area. Journal of Veterinary Cardiology 8, 49-53.

Hyun C., Park I. (2006). Congenital heart diseases in small animals: Part II. Potential genetic aetiologies based on human genetic studies. The Veterinary Journal 171, 256-262.
Falk T., Jönsson L., Pedersen H. D. (2004). Intramyocardial arterial narrowing in dogs with subaortic stenosis. Journal of Small Animal Practice 45, 448-453.

Kienle R. D. (1998). Aortic stenosis. In: Kittleson M. D., Kienle R. D. (editors). Small Animal Cardiovascular Medicine, Mosby Inc., St. Louis, p. 260-272.

MacDonald K. A. (2006). Congenital heart diseases of puppies and kittens. The Veterinary Clinics of North America. Small Animal Practice 36, 510-514.

Muna W. F., Ferrans V. J., Pierce J. E., Roberts W. C. (1977). Ultrastructure of the fibrous subaortic "ring" in dogs with discrete subaortic stenosis. Circulation 56, 206-217.

Muna W. F. , Ferrans V. J., Pierce J. E., Roberts W. C. (1978). Discrete subaortic stenosis in newfoundland dogs: Association Of Infective Endocarditis. The American Journal of Cardiology 41, 746-754.

O’Grady M. R., Holmberg D. L., Miller C. W., Cockshutt J. R. (1989). Canine congenital aortic stenosis: a review of the literature and commentary. Canine Veterinary Journal 30, 811-815.

Oyama M. A., Thomas W. P. (2002). Two-dimensional and m-mode echocardiographic predictors of disease severity in dogs with congenital subaortic stenosis. Journal of the American Animal Hospital Association 38, 209-215.

Padgett G. A. (1998). Control of Canine Genetic Diseases, Howell Book House, New York, p. 166-167.

Peelman L. J. (2009). Erfelijke Afwijkingen bij de Hond, Euroscience, Bilthoven, p. 90-91.

Pyle R. L., Patterson D. F., Chacko S. (1976). The genetics and pathology of discrete subaortic stenosis in the Newfoundland dog. American Heart Journal 92, 324-334.

Riesen S. C., Doherr M. G., Lombard C. W. (2007). Comparison of Doppler-derived aortic velocities obtained from various transducer sites in healthy dogs and cats. Veterinary Radiology and Ultrasound 48, 570-573.

Ware W. (2007). Cardiovascular Disease in Small Animal Medicine, Manson Publishing, London, p. 68-90, 230233. 